\title{
Design, Development and Characterization of Sustain Release Matrix Type Tablet of Cinnarazine
}

\author{
Suman Gehlot* and Sumeet Dwivedi \\ College of Pharmacy, Dr. APJ Abdul Kalam University, India \\ Received: October 14, 2017; Published: October 24, 2017 \\ *Corresponding author: Suman Gehlot, College of Pharmacy, Dr. APJ Abdul Kalam University, Indore; India, Tel: +91-9893478497; \\ Email: sumangehlot81@gmail.com; herbal0914@rediffmail.com
}

\begin{abstract}
The objective of this study was to design and evaluate oral sustain release drug delivery system for Cinnarazine using hydrophilic polymers such as and HPMC (K100M), PVP (K) batches. Four batches were prepared by using HPMC (K100M) in drug: Polymer ratio of 1:1, 1:1.5, 1:2, 1:3 and five batches using PVP (K) in ratios of 1:1, 1:1.25, 1:1.5, 1:1.75 and 1:2. Further formulation F9 was modified by varying the ratios of diluents i.e F10, F11, F12 and F13 to check the effect of diluents on drug release. Matrix tablets were prepared by wet granulation method and were evaluated. Among the formulations studied, formulation F9 containing HPMC K100M (1:2) showed sustained release effect for $20 \mathrm{~h}$ with cumulative percent release of $88 \%$ similar to that of the research listed drug. The kinetic treatment showed that the optimized formulation follow first order kinetic with release exponent (n) 0.579 and having good stability as per ICH guidelines. Key Words: Sustained release, Hydrophilic gums, HPMC (K100M)/ (PVP (K), Magnesium stearate, Lactose and drug Cinnarazine.
\end{abstract}

Keywords : Sustain release; Matrix tablet; Cinnarazine

Abbreviations : DSC: Differential Scanning Calorimetry; FTIR: Fourier Transform Infrared

\section{Introduction}

Sustained release, sustained action, prolonged action controlled release, extended action, timed release, depot and repository dosage forms are terms used to identify drug delivery system that are designed to achieve or prolonged therapeutic effect by continuously releasing medication over an extended period of time after administration of a single dose. On exposure to aqueous fluid, hydrophilic matrices take up water, and the polymer starts hydrating to form a gel layer. Drug release is controlled by a gel diffusion barrier and/or by surface erosion. An initial burst of soluble drug may occur due to the surface leaching. When a matrix containing a sellable glassy polymer comes in contact with an aqueous medium, there is an abrupt change from a glassy to a rubbery state, which is associated with the swelling process.

\section{Pre-Formulation Study}

\section{Identification of Drug}

\section{Physical Appearance}

Through visual inspection, the physical appearance of pure drug was carried out as per United State Pharmacopeia XV. The Melting point was determined by the capillary method using Melting point apparatus. The capillary tube was filled by pressing the open end gently into pure drug sample by tapping the bottom of the capillary on a hard surface so that the drug pack down into the bottom of the tube. When the drug was packed into the bottom of the tube, the tube was place into the slot behind the eye-piece on the Melttemperature. Make sure the units were plug in and set to zero, and then turn it on. Temperature range was noted when sample start melting. Triplicate observations were recorded for melting range

\section{Solubility Study}

A definite quantity (10 mg) of drug was dissolved in $10 \mathrm{ml}$ of each investigated solvents at room temperature. The solubility was observed only by UV method.

\section{Partition Coefficient}

The partition coefficient of drug was determined in n-octanol: water system (50:50) in triplicate by standard technique. A weighed amount of drug (10mg) was added into $10 \mathrm{ml}$ each of n-octanol and water. The mixture was shaken for $24 \mathrm{hrs}$ until equilibrium was reached. Phase was separated in separating funnel and aqueous and non-aqueous phase was filtered (through $0.2 \mu$ filter) and analyzed by using UV spectrophotometer. The partition coefficient $(\mathrm{Po} / \mathrm{w})$ of drug was calculated from the ratio between the concentrations of drug in organic (Coil) and aqueous phase (Caq.) using following equation [2]. 


\section{Molecular Weight of the Drug}

Diffusivity, the ability of a drug to diffuse through the membranes, is inversely proportional to molecular size. For most polymers it is possible to relate log D, Empirically to some function of molecular size as follows.

$$
\begin{aligned}
\log \mathrm{D} & =-\mathrm{s}_{\mathrm{V}} \log \mathrm{v}+\mathrm{k}_{\mathrm{V}} \\
& =-\mathrm{s}_{\mathrm{M}} \log _{\mathrm{M}}+\mathrm{k}_{\mathrm{m}} \ldots \ldots \ldots \ldots \ldots \ldots \ldots \ldots
\end{aligned}
$$

\section{UV Spectrophotometry: Preparation of standard curve}

Preparation of cinnarazine standard stock solution $(100 \mu \mathrm{g} /$ $\mathrm{ml}$ ) in $0.01 \mathrm{~N} \mathrm{HCL}$

Cinnarazine was accurately weighed $10 \mathrm{mg}$ of cinnarazine in $10 \mathrm{ml}$ volumetric flask. The volume was then made upto $100 \mathrm{ml}$ by using $0.01 \mathrm{~N}$ HCL solution to obtain the solution of $100 \mu \mathrm{g} / \mathrm{ml}$. From the Cinnarazine stock solution $(100 \mu \mathrm{g} / \mathrm{ml}) 1 \mathrm{ml}$ was pippeted and diluted to $10 \mathrm{ml}$ by using $0.01 \mathrm{~N}$ HCL solution into different volumetric flask and made upto $10 \mathrm{ml}$ with $0.01 \mathrm{~N}$ HCL solution so as to get concentration of 1.0 to $10.0 \mu \mathrm{g} / \mathrm{ml}$

\section{Determination of analytical wavelength}

From the standard stock solution $1 \mathrm{ml}$ was pippeted into a volumetric flask. The volume was made upto $10 \mathrm{ml}$ with $0.01 \mathrm{~N}$ HCL solution. The resulting solution containing $10 \mu \mathrm{g} / \mathrm{ml}$ was scanned between $200-400 \mathrm{~nm}$ the $\lambda_{\max }$ was found to be $252 \mathrm{~nm}$ [3].

\section{Calibration curve of cinnarazine in $0.01 \mathrm{~N}$ HCL solution}

From the Cinnarazine stock solution $(100 \mu \mathrm{g} / \mathrm{ml}) 1 \mathrm{ml}$ was pippeted and diluted to $10 \mathrm{ml}$ by using $0.01 \mathrm{~N}$ HCL solution. From the solution appropriate aliquots was taken into different volumetric flask and made up to $10 \mathrm{ml}$ with $0.01 \mathrm{~N}$ HCL solution so as to get concentration of 1.0 to $10.0 \mu \mathrm{g} / \mathrm{ml}$ [4].

\section{Preparation of Granules by Wet Granulation Method}

The Drug (Cinnarazine), polymer HPMC (K100M), PVP (K), all the excipients magnesium stearate and lactose were passed through sieve no. 80 separately. Nine different formulations with polymer ratios were prepared i.e. $1: 1,1: 1.5,1.2,1: 2.5,1: 3,1: 3.5,1: 4,1: 4.5$ and $1: 5$ by keeping the amount of lactose at $30 \mathrm{mg}$ and Cinnarazine at $375 \mathrm{mg}$ constant with magnesium stearate $2 \% \mathrm{w} / \mathrm{w}$. After sieving all ingredients were mixed in mortar. Prepared mixture was passed through sieve no.40 and transferred the ingredient mixture in clean mortar. Added isopropyle alcohol sufficient quantity in mixed powder for preparing dump mass. The dump mass mixture was passed through sieve no. 22. After sieving this mixture was dried in hot air oven for $30 \mathrm{~min}$.

\section{Characterization of Granules}

\section{Angle of Repose}

It can be done by taking the accurately weighed powder blend and allowing it to flow freely through the funnel, fixed to a stand at definite height. The height (h) and diameter (d) of the powder cone are measured and the angle of repose can be calculated by the formula, $\tan \theta=h / r$ (or) $\theta=\tan ^{-1} h / r$.

\section{Bulk Density}

Bulk density ( $\mathrm{Db}$ ) is the ratio of weight of the untapped powder sample to its initial volume \& it was determined by following formula. ( $\mathrm{w}=$ weight of the untapped powder, $\mathrm{Vb}=$ initial volume)

$$
\text { Bulk density }\left(D_{b}\right)=W / V_{b} \text {. }
$$

\section{Tapped Density}

Tapped density (Dt) is the ratio of weight of the powder sample to its tapped volume \& it was determined by following formula. ( $w$ = Weight of powder sample, $\mathrm{Vt}=$ Tapped volume) .

It is calculated using following formula: Tapped density $(D t)=W / V t$

\section{Compressibility index (Carr's Index)}

The Carr's compressibility index (also called as Carr's Consolidation index or Carr's Index) was calculated using following formula: Carr's Compressibility index $=(D t-D b) / D t \times 100$.

\section{Hausner's Ratio}

Hausner's ratio was calculated from the measured values of tapped density (Dt) and bulk density (Db), as follows, Hausner's ratio $=D t / D b$.

\section{Drug-excipient interaction studies}

Preformulation studies are very important for the successful formulation of any dosage form. Differential Scanning Calorimetry (DSC), Fourier Transform Infrared(FTIR)Spectroscopystudies(Joshi et al.,) and HPTLC were used for the evaluation of physicochemical compatibility and interactions, which helps in the prediction of interaction of the drug with polymers, diluents and lubricants used in case tablet formulations. Positive interactions sometimes have a beneficial effect as far as desired release parameters are concerned. The earlier investigations recommended that the ratio of drug to excipients used in study was 1:5 for diluents, 3:1 for binders or dis-integrants, 5:1 for lubricants and 10:1 for colorants etc, but it is observed that $1: 1$ ratio of drug excipients maximizes the possibility of interaction and helps in easier detection of incompatibilities 17. Therefore, in the present study 1:1 ratio was used for preparation of physical mixtures and analyzed for compatibility studies [5].

\section{Methodology}

\section{Preparation of standard curve}

\section{Preparation of Standard Curve of Cinnarazine in $0.1 \mathrm{~N} \mathrm{HCl}(\mathrm{pH}$} 1.2)

$10 \mathrm{mg}$ drug was dissolved in $100 \mathrm{ml}$ of $0.1 \mathrm{~N} \mathrm{HCl} \&$ from these different dilutions were prepared in concentration range of 5,10 , $15,20,25,30,35,40,45,50, \mu \mathrm{g} / \mathrm{ml} \&$ absorbance was taken at 252 $\lambda_{\max }$ nm (Figure 1).

\section{Preparation of Standard Curve of Cinnarazine in (PBS) pH 6.8:}

$10 \mathrm{mg}$ drug was dissolved in $100 \mathrm{ml}$ PBS from these different dilutions were prepared in concentration range of $5,10,15,20,25$, $30,35,40,45,50 \mu \mathrm{g} / \mathrm{ml} \&$ absorbance was taken at $252 \lambda_{\max } \mathrm{nm}$ (Table 1). 


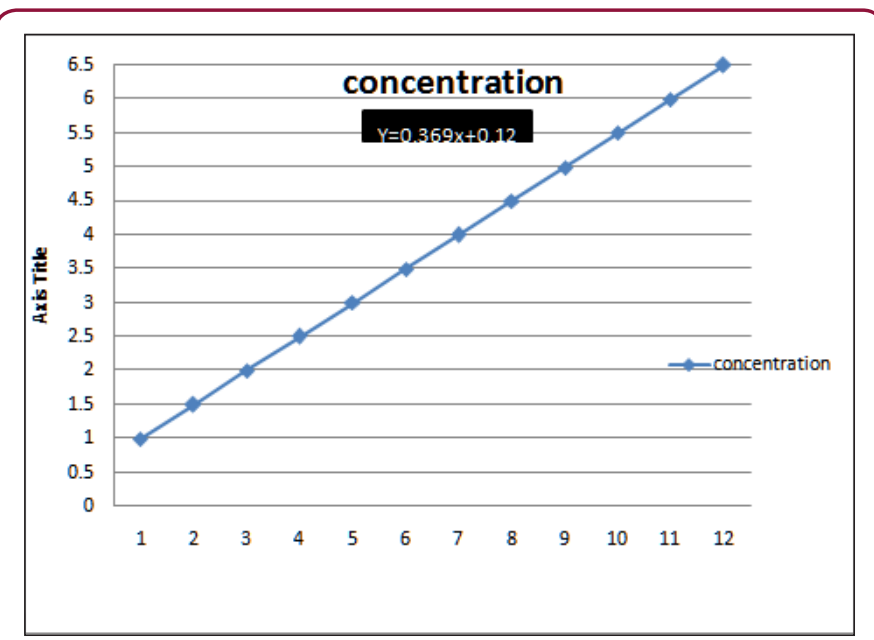

Figure 1 : Standard plot of Cinnarazine in $0.1 \mathrm{~N} \mathrm{HCL}$ solution.

Table 1 : Standard plot of Cinnarazine in 0.1 N HCL solution.

\begin{tabular}{|c|c|c|}
\hline S.No & $\begin{array}{c}\text { Concentration }(\boldsymbol{\mu g} / \\
\mathbf{m l})\end{array}$ & $\begin{array}{c}\text { Absorbance at } \\
\mathbf{2 5 2 n m}\end{array}$ \\
\hline 1. & 1 & 0.456 \\
\hline 2. & 1.5 & 0.650 \\
\hline 3. & 2 & 0.859 \\
\hline 4. & 2.5 & 1.066 \\
\hline 5. & 3 & 1.247 \\
\hline 6. & 3.5 & 1.462 \\
\hline 7. & 4 & 1.628 \\
\hline 8. & 4.5 & 1.814 \\
\hline 9. & 5 & 1.944 \\
\hline 10. & 5.5 & 2.199 \\
\hline 11. & 6 & 2.339 \\
\hline 12. & 6.5 & 2.461 \\
\hline
\end{tabular}

\section{Preparation of Granules}

All the excipients and drug was weighed and sieved properly and triturated with the help of isopropyl alcohol according to geometric dilution. This mixture was passed through sieve no. 22. After sieving this mixture was then dried [6].

\section{Preparation of Sustain Release Tablet by Direct Compression Method}

\section{Punching of Granules / Tablet compression}

The matrix tablets of the above formulations were compressed in a single punch tablet compression machine. A weighted amount of the sustain release granules was introduced in the die and the die capacity was adjusted as required. Compression force was adjusted to obtain the required hardness. A batch of 9 tablets was prepared for all formulations (Tables 2-4).
Table 2: Formulations Containing Drug \& HPMC (K100M).

\begin{tabular}{|c|c|c|c|c|c|}
\hline S. No. & $\begin{array}{c}\text { INGREDIENTS } \\
\text { (mg/tab) }\end{array}$ & $\begin{array}{c}\text { F9 (mg/ } \\
\text { tab) }\end{array}$ & $\begin{array}{c}\text { F10 } \\
\text { (mg/ } \\
\text { tab) }\end{array}$ & $\begin{array}{c}\text { F11 } \\
\text { (mg/ } \\
\text { tab) }\end{array}$ & $\begin{array}{c}\text { F12 } \\
\text { (mg/ } \\
\text { tab) }\end{array}$ \\
\hline 1. & Cinnarazine & $525 \mathrm{mg}$ & $525 \mathrm{mg}$ & $525 \mathrm{mg}$ & $525 \mathrm{mg}$ \\
\hline 2. & HPMC(K100M) & $24 \mathrm{mg}$ & $22 \mathrm{mg}$ & $20 \mathrm{mg}$ & $18 \mathrm{mg}$ \\
\hline 3. & PVP(K) & $20 \mathrm{mg}$ & $20 \mathrm{mg}$ & $20 \mathrm{mg}$ & $20 \mathrm{mg}$ \\
\hline 4 & $\begin{array}{c}\text { Magnesium } \\
\text { stereate }\end{array}$ & $4 \mathrm{mg}$ & $4 \mathrm{mg}$ & $4 \mathrm{mg}$ & $4 \mathrm{mg}$ \\
\hline 5. & Lactose & $28 \mathrm{mg}$ & $28 \mathrm{mg}$ & $28 \mathrm{mg}$ & $28 \mathrm{mg}$ \\
\hline 6. & Total & $601 \mathrm{mg}$ & $599 \mathrm{mg}$ & $597 \mathrm{mg}$ & $595 \mathrm{mg}$ \\
\hline
\end{tabular}

$\underline{\text { Table } 3}$ : Formulations Containing Drug \& PVP (K).

\begin{tabular}{|c|c|c|c|c|c|}
\hline S. No. & $\begin{array}{c}\text { INGREDIENTS } \\
\text { (mg/tab) }\end{array}$ & $\begin{array}{c}\text { F5 (mg/ } \\
\text { tab) }\end{array}$ & $\begin{array}{c}\text { F6 (mg/ } \\
\text { tab) }\end{array}$ & $\begin{array}{c}\text { F7 (mg/ } \\
\text { tab) }\end{array}$ & $\begin{array}{c}\text { F8 (mg/ } \\
\text { tab) }\end{array}$ \\
\hline 1. & Cinnarazine & $525 \mathrm{mg}$ & $525 \mathrm{mg}$ & $525 \mathrm{mg}$ & $525 \mathrm{mg}$ \\
\hline 2. & HPMC(K100M) & $22 \mathrm{mg}$ & $22 \mathrm{mg}$ & $22 \mathrm{mg}$ & $22 \mathrm{mg}$ \\
\hline 3. & PVP(K) & $20 \mathrm{mg}$ & $22 \mathrm{mg}$ & $18 \mathrm{mg}$ & $24 \mathrm{mg}$ \\
\hline 4 & $\begin{array}{c}\text { Magnesium } \\
\text { stereate }\end{array}$ & $4 \mathrm{mg}$ & $4 \mathrm{mg}$ & $4 \mathrm{mg}$ & $4 \mathrm{mg}$ \\
\hline 5. & Lactose & $28 \mathrm{mg}$ & $28 \mathrm{mg}$ & $28 \mathrm{mg}$ & $28 \mathrm{mg}$ \\
\hline 6. & Total & $599 \mathrm{mg}$ & $601 \mathrm{mg}$ & $597 \mathrm{mg}$ & $603 \mathrm{mg}$ \\
\hline
\end{tabular}

Table 4 : Formulations containing drug, HPMC (K100M) \& various concentrations of excipients.

\begin{tabular}{|c|c|c|c|c|c|}
\hline S. No. & $\begin{array}{c}\text { INGREDIENTS } \\
\text { (mg/tab) }\end{array}$ & $\begin{array}{c}\text { F9 } \\
\mathbf{( m g} / \\
\text { tab) }\end{array}$ & $\begin{array}{c}\text { F10 } \\
\mathbf{( m g} / \\
\text { tab) }\end{array}$ & $\begin{array}{c}\text { F11 } \\
\mathbf{( m g} / \\
\text { tab) }\end{array}$ & $\begin{array}{c}\text { F12 (mg/ } \\
\text { tab) }\end{array}$ \\
\hline 1. & Cinnarazine & $525 \mathrm{mg}$ & $525 \mathrm{mg}$ & $525 \mathrm{mg}$ & $525 \mathrm{mg}$ \\
\hline 2. & HPMC(K100M) & $22 \mathrm{mg}$ & $22 \mathrm{mg}$ & $22 \mathrm{mg}$ & $22 \mathrm{mg}$ \\
\hline 3. & PVP(K) & $20 \mathrm{mg}$ & $20 \mathrm{mg}$ & $20 \mathrm{mg}$ & $20 \mathrm{mg}$ \\
\hline 4. & $\begin{array}{c}\text { Magnesium } \\
\text { stereate }\end{array}$ & $4 \mathrm{mg}$ & $4 \mathrm{mg}$ & $4 \mathrm{mg}$ & $4 \mathrm{mg}$ \\
\hline 5. & Lactose & $28 \mathrm{mg}$ & $28 \mathrm{mg}$ & $28 \mathrm{mg}$ & $28 \mathrm{mg}$ \\
\hline 6. & Total & $599 \mathrm{mg}$ & $607 \mathrm{mg}$ & $595 \mathrm{mg}$ & $595 \mathrm{mg}$ \\
\hline
\end{tabular}

Post Formulation Studies / Evaluation of characteristics of powder blend and tablets

The various characteristics of powder blend like bulk density, tapped density, angle of repose, particle size and drug content were studied. The formulated tablets were evaluated for hardness, friability, uniformity of weight and drug content.

\section{Thickness}

The thickness of tablets was determined by using vernier caliper. Five tablets from each batch were used \& average values were calculated [7].

\section{Disintegration Test}

The test was carried out on six tablets using disintegrating apparatus in distilled water medium at $37 \pm 1^{\circ} \mathrm{C}$. The average $\mathrm{D}$. T. was recorded [8-15]. 


\section{Hardness Test}

The hardness test was done for five tablets using Monsanto hardness tester, \& the average value was recorded [16].

\section{Friability Test}

This test was performed on 20 tablets using Roche friabilator. The tablets were weighed and put in the friabilator, after 100 revolutions, the tablets was redusted and weighed. Percent loss in weight will be recorded. This can be calculated with the help of following formula, $\% \mathrm{~F}=$ Loss in weight/ Initial weight $\mathrm{x} 100$ [17].

$$
\% \mathrm{~F}=\frac{w_{1}-w_{2}}{w_{1}} \times 100
$$

\section{Weight Variation Test \& its Limit according to USP - XV}

This test was done as per the guidelines of USP, tablets will randomly sampled and take individual weight of 20 tablets in analytical balance and determine standard deviation (Table 5).

Table 5: Limits for weight variation (USP - XV).

\begin{tabular}{|c|c|c|}
\hline Dosage Form & Average Weight & \% Deviation \\
\hline \multirow{2}{*}{$\begin{array}{c}\text { Uncoated/Coated Film } \\
\text { tablets }\end{array}$} & $\begin{array}{c}\text { More than } 80 \mathrm{mg} \text { but } \\
\text { less than } 250 \mathrm{mg}\end{array}$ & 7.5 \\
\cline { 2 - 3 } & $250 \mathrm{mg}$ or more & 5 \\
\hline
\end{tabular}

\section{Drug Content}

Five tablets were weighed and triturate, from that transfer an accurately weighed portion of the powder equivalent to about $95 \mathrm{mg}$ of cinnarazine to a $100 \mathrm{ml}$ volumetric flask containing buffer solution and then concentration is measured at $\lambda_{\max }$ i.e $252 \mathrm{~nm}$.

\section{Compression Force}

The influence of compression force could only be observed in lag time. Tablets made at lowest crushing strength (compression force $3 \mathrm{KN}$ ) with Methocel K4 M showed an initial burst effect due to initial partial disintegration. Once the polymer was swollen, the dissolution profile became similar to the tablets compressed with a higher crushing strength. It has been reported that changes in compression force or crushing strength appeared to have minimal effect on drug release from HPMC matrix tablet once a critical hardness is achieved. Increased dissolution was only observed when tablets were too soft and it was attributed to the lack of powder compaction or consolidation (3 KP) [18].

\section{Tablet Shape}

The size and shape of tablet for the matrix system undergoing diffusion and erosion might affect the drug dissolution rate. Modification of surface area for metoprolol tartarate tablets formulated with Methocel K100 LV from standard concave shape ( $0.568 \mathrm{sq}$ in) to caplet shape $(0.747 \mathrm{sq}$ in) showed an approximately 20-30\% increase in dissolution at each time point.

\section{In-vitro Dissolution Test}

The dissolution studies were performed in triplicate for all the batches in a USP XXIII dissolution rate test apparatus (type II). The release studies were performed at $75 \mathrm{rpm}$ in $900 \mathrm{ml}$ of $0.1 \mathrm{~N} \mathrm{HCl}$ buffer $\mathrm{pH} 1.2$ at $37 \pm 0.2 \mathrm{oC}$. Five milliliters aliquots were withdrawn at predefined intervals, and the volume of the dissolution medium was maintained by adding the same volume of fresh prepared warmed dissolution medium. The absorbance of the withdrawn samples was measured spectrophotometer at $252 \mathrm{~nm}$.

\section{Stability Studies}

The optimized formulation was subjected for two month stability study according to ICH guidelines. The selected formulations were packed in aluminum foils, which were in wide mouth bottles closed tightly. They were then stored at $40^{\circ} \mathrm{C} / 75 \%$ RH for 2 months and evaluated for their drug release study.

\section{Result and Discussion}

\section{Physical Appearance}

Physical appearance of Cinnarazine sample complies the USP standard (Table 6).

Table 6 : Physical Appearance of Cinnarazine.

\begin{tabular}{|c|c|}
\hline USP - XV Standard & Sample \\
\hline $\begin{array}{c}\text { White to off white crystalline } \\
\text { powder }\end{array}$ & white powder \\
\hline
\end{tabular}

\section{Melting Point}

According to USP XV the melting point of Torsemide (Standard) is $163-1640 \mathrm{C}$ and melting of sample was found to be in the range of 161-1640 C (Table 7).

Table 7 : Determination of Melting Point of Cinnarazine.

\begin{tabular}{|c|c|}
\hline USP - XV Standard & Sample \\
\hline $118-1220 \mathrm{C}$ & $118-1220 \mathrm{C}$ \\
\hline
\end{tabular}

\section{Solubility Study}

Solubility of cinnarazine was determined in solvents given the table (Table 8).

Table 8 : Determination of Solubility of Cinnarazine.

\begin{tabular}{|c|c|c|}
\hline S. No. & Solvent & Solubility \\
\hline 1 & $0.1 \mathrm{~N} \mathrm{HCl}$ & Soluble \\
\hline 2 & $0.1 \mathrm{~N} \mathrm{NaOH}$ & Soluble \\
\hline 3 & Ethanol & Soluble \\
\hline 4 & Water & Insoluble \\
\hline 5 & Ether & Soluble \\
\hline 6 & Dioxane & Soluble \\
\hline
\end{tabular}

\section{Partition Coefficient}

The partition coefficient of Cinnarazine was determined (Table 9).

Table 9: Determination of Partition Coefficient of Cinnarazine.

\begin{tabular}{|c|c|}
\hline USP - XV Standard & Sample \\
\hline Log P (dioxane/water), 9.85 & Log P(dioxane /water), 9.80 \\
\hline
\end{tabular}




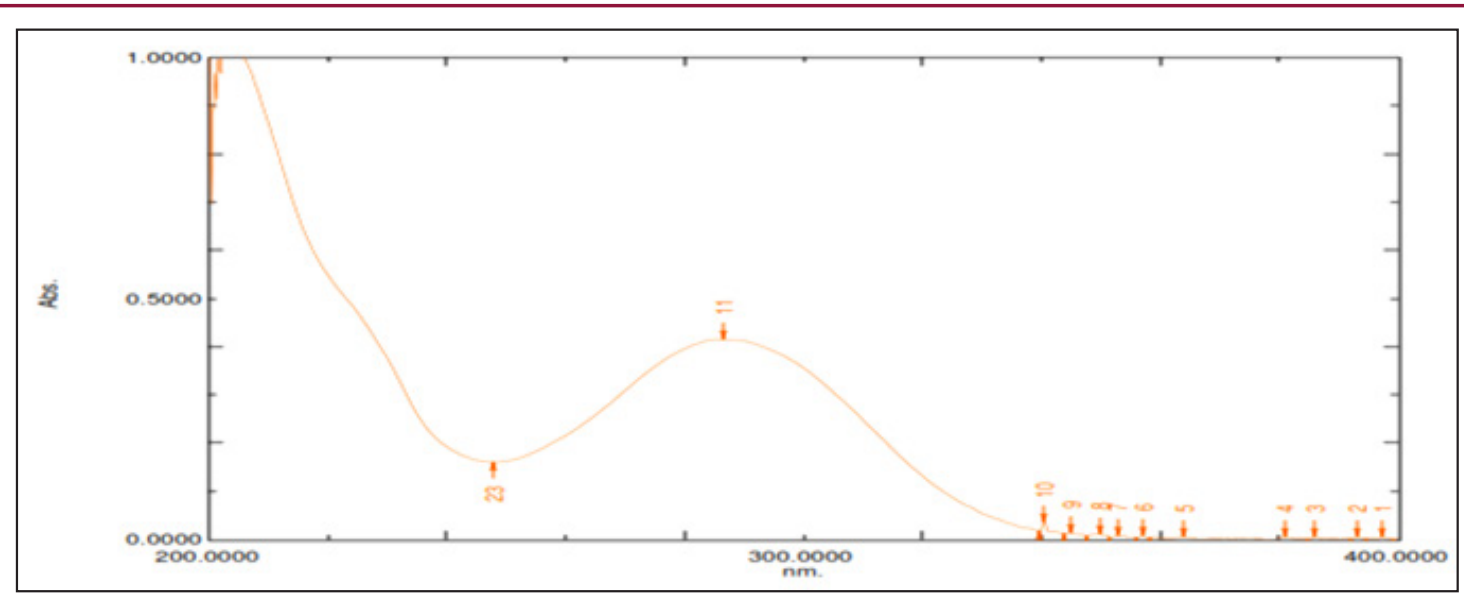

Figure 2 : Absorption Maxima of Cinnarazine in 252nm.

\section{Determination of Absorption Maxima}

The UV absorption maxima were determined by scanning solution of Cinnarazine in the range of 200-400 nm by Shimadzu - $1800 \mathrm{UV} /$ Visible spectrophotometry, and it was found to be 252 nm (Figures $1 \& 2$ ).

\section{'Pre-compression Studies of SR-Release Granules}

The characterizations of different SR release granules were done for determination of mass-volume relationship parameters. The evaluated parameters are bulk density, tapped density, compressibility index, and angle of repose, Carr's index, Hausner's ratio (Table 10).

$\underline{\text { Table } 10}$ : Pre-compression of Sustain Release Granules.

\begin{tabular}{|c|c|c|c|c|c|}
\hline \multirow{2}{*}{ Batch } & \multicolumn{5}{|c|}{ Parameters } \\
\cline { 2 - 6 } & Bulk density (g/ml) & $\begin{array}{c}\text { Tapped density (g/ } \\
\mathbf{m l})\end{array}$ & Carr's index & Hausner's ratio & Angle of repose ( $\Theta$ ) \\
\hline IRF1 & $0.420 \pm 0.0060$ & $0.483 \pm 0.0041$ & $12.691 \pm 0.6264$ & $1.150 \pm 0.0120$ & $36.753 \pm 0.475$ \\
\hline IR F2 & $0.459 \pm 0.0056$ & $0.561 \pm 0.0024$ & $13.791 \pm 1.108$ & $1.201 \pm 0.0152$ & $35.992 \pm 0.450$ \\
\hline IR F3 & $0.489 \pm 0.0032$ & $0.532 \pm 0.0075$ & $15.535 \pm 0.6459$ & $1.170 \pm 0.0123$ & $34.822 \pm 0.335$ \\
\hline IR F4 & $0.494 \pm 0.0022$ & $0.527 \pm 0.0019$ & $16.404 \pm 0.8356$ & $1.211 \pm 0.0143$ & $33.520 \pm 0.300$ \\
\hline
\end{tabular}

Table 11 : Post-compression Studies of Sustain Release Tablets.

\begin{tabular}{|c|c|c|c|c|c|}
\hline \multirow[b]{2}{*}{ Batch code } & \multicolumn{5}{|c|}{ Parameters } \\
\hline & Thickness (mm) & $\begin{array}{l}\text { Hardness } \\
\left(\mathrm{Kg} / \mathrm{cm}^{2}\right)\end{array}$ & $\begin{array}{c}\text { Friability } \\
\text { (\%) }\end{array}$ & Weight variation & $\begin{array}{c}\text { Disintegration time } \\
\text { (sec) }\end{array}$ \\
\hline IR F1 & $2.27 \pm 0.0022$ & $5.79 \pm 0.1456$ & $0.598 \pm 0.154$ & $480.15 \pm 0.206$ & $35.39 \pm 0.449$ \\
\hline IR F2 & $2.33 \pm 0.0030$ & $5.40 \pm 0.1400$ & $0.555 \pm 0.0220$ & $480.22 \pm 0.159$ & $34.54 \pm 0.364$ \\
\hline IR F3 & $2.40 \pm 0.0015$ & $5.43 \pm 0.1557$ & $0.461 \pm 0.0285$ & $480.18 \pm 0.134$ & $33.06 \pm 0.246$ \\
\hline IR F4 & $2.28 \pm 0.0026$ & $5.30 \pm 0.6784$ & $0.633 \pm 0.3651$ & $481.19 \pm 0.287$ & $28.83 \pm 0.0164$ \\
\hline
\end{tabular}

\section{Post-compression Studies of SR-Release Matrix-Type Tablets}

The characterizations of sustain release tablets were done. The evaluated parameters were thickness, hardness, friability, weight variation, disintegration which are given in table (Table 11).

\section{In-vitro Release for SR-Release Matrix-Type Tablet of Cinnarazine in $0.1 \mathrm{~N}$}

HCL: In-vitro drug release studies were performed \& drug release data of different formulation are given in table (Table 12) (Figure 3). 


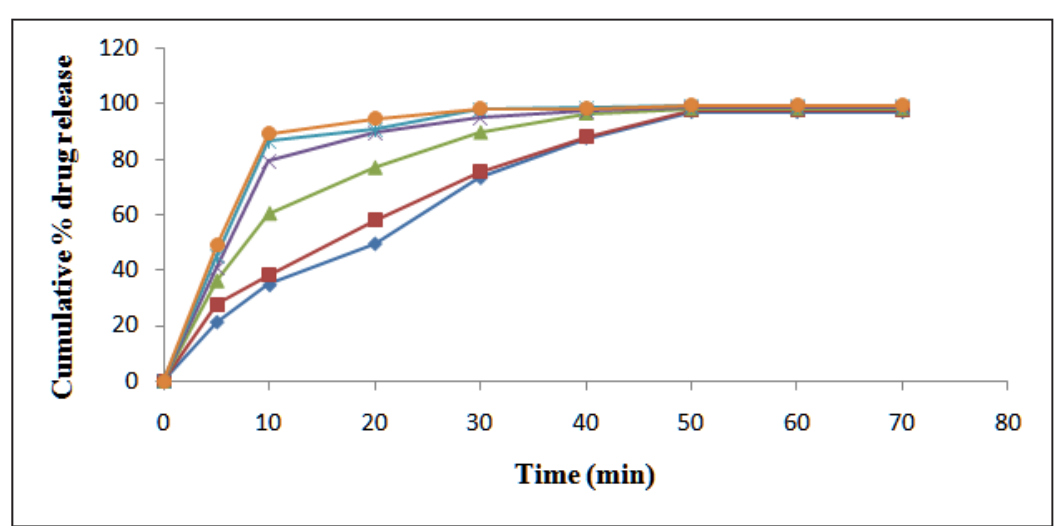

Figure 3 : In-vitro Drug Release Profile of SR-Release Matrix-Type Tablet of Cinnarazine.

Table 12: In-vitro Release for SR-Release Matrix-Type Tablet of Cinnarazine in $0.1 \mathrm{~N} \mathrm{HCl}$.

\begin{tabular}{|c|c|c|c|c|c|}
\hline \multirow{2}{*}{ S. no. } & \multirow{2}{*}{$\begin{array}{c}\text { Time } \\
\text { (min) }\end{array}$} & \multicolumn{4}{|c|}{ Cumulative \% release } \\
\hline & & IR F1 & IR F2 & IR F3 & IR F4 \\
\hline 1 & 0 & 0 & 0 & 0 & 0 \\
\hline 2 & 5 & 22.31 & 24.23 & 46.13 & 45.41 \\
\hline 3 & 10 & 32.68 & 26.14 & 67.55 & 80.44 \\
\hline 4 & 20 & 50.50 & 56.25 & 72.88 & 86.54 \\
\hline 5 & 30 & 74.23 & 76.07 & 88.51 & 94.25 \\
\hline 6 & 40 & 86.61 & 88.15 & 95.47 & 96.04 \\
\hline 7 & 50 & 96.00 & 98.88 & 98.20 & 98.58 \\
\hline 8 & 60 & 96.00 & 98.84 & 98.24 & 98.55 \\
\hline 9 & 70 & 96.00 & 98.80 & 98.26 & 98.52 \\
\hline
\end{tabular}

\section{Conclusion}

Cinnarazine Sustain Release matrix-Type Tablets, In preliminary studies various formulation combinations and parameters such as concentration of lactose, magnesium stearate, HPMC \& PVP were varied during the drug loading stage, $\mathrm{PVP}(\mathrm{K})$ they are responsible to produce increase solubilization \& fast release of drug and to produce immediate effect in GIT. For SR, Four different SR release batches using HPMC(K100m) (F1,F2,F3,F4) and Four SR release formulation using PVP (K) (F5, F6, F7, F8) and two SR release formulation using excipeint lactose \& magnesium stearate (F9, F10, F11, F12) was prepared. After performing the pre and post formulation studies on these batches it was found that IR-6 shows the best immediate release profile and SR F-2 shows the best sustained release profile. So by taking IR- 6 \& SR F-2 a final batch (M1) of Sustain Release matrix-Type Tablet was prepared.

Post formulation studies on the batch (M1) were performed. The average thickness of the tablets was found to be $2.51 \pm 0.0012$ $\mathrm{mm}$, the average hardness was found to be $5.11 \pm 0.1024 \mathrm{~kg} / \mathrm{cm}^{2}$, the average friability was found to be $0.43 \pm 0.0051 \%$ \& it passed the friability test. The SR tablet also passed the weight variation test and the average disintegration time was found to be $25 \pm 0.0015$ seconds. The in-vitro dissolution studies were carried out \& the SR tablet released $95.45 \%$ of drug over the time period of 10 hours.

\section{References}

1. Lachman L, Liberman HA, Kanig JL (1976) The theory and practice of industrial pharmacy $\left(2^{\text {nd }} \mathrm{edn}\right)$. Varghese publishing house, India.

2. Aulton ME (2002) Pharmaceutics the science of dosage form design $\left(2^{\text {nd }}\right.$ edn). Churchill livingstone, London, UK, 4: 365-380.

3. Vyas SP, Goyal AK, Rath G (2011) Handbook of pharmaceutical dosage form ( $1^{\text {st }}$ edn). vallabh prakashan, New Delhi, India.

4. Jain NK (2006) Pharmaceutical product development (1 $1^{\text {st }}$ edn). CBS publishers and distributors, New Delhi, India.

5. Sanmathi BS, Mehta KK, Gupta A (2010) Dispensing pharmacy a practical manual ( $3^{\text {rd }}$ edn). Pharma Med press, Hyderabad, India.

6. Ansel HC, Popovich NG, Loyd AV (2006) Ansels pharmaceutical dosage forms and drug delivery systems ( $\left.8^{\text {th }} \mathrm{edn}\right)$. BI publications, India.

7. Pathikkumar J Maravaniya K, Tanvee M, Deshpande R, Shinde V (2013) Multiple Unit Pellet System-A New Path for Drug Delivery. International Journal of Universal Pharmacy and Bio Sciences 2(4): 401-415.

8. Ibrahim M Bagory E, Brakat N, Badry M, Mohmed A, Enazi F (2010) Effect of polymer blend on diltiazem Hydrochloride matrix tablet prepared by direct compression. Journal of Science \& Pharmaceutical Technology 2(7): 252-268.

9. John CP, Nomeir AM, Fowle K, Dalane WK, Kevin M Rankin, et al. (2001) The Pathogenesis of Acute Pulmonary Edema Associated with Hypertension. New England Journal of Medicine 344: 17-22.

10. G M El-Mahrouk, M A Al-Meshal, A A Al-Angary, G M Mahrous (1993) Drug Development and Industrial Pharmacy 19(15): 1903-1916.

11. Pinto JF, Podczeck F, Newton JM (1996) Investigations of tablets prepared from pellets produced by extrusion and spheronization. International journal of pharmaceutics pp. 79-96.

12. Wagner KG, Krumme M, Beckert TE, Schmidt PC (2000) European Journal of Pharmaceutics and Biopharmaceutics 50(2): 285-291.

13. Kim TW, Tae Wan J, Chang Won S, Sang Y, Lee B (2007) Archives of Pharmacal Research 30(1): 124-130.

14. Kishore VS, Rao BT, Y Kumar S, Nagasen D (2013) Design of Orodispersible Tablets of Losartan Potassium Using Novel Co-Processed Superd is integrants RRJPPS 2(3): 42-51.

15. Kamboj M, Goyal S, Rakha P, Arora G, Dureja H, Nagpal M et al. (2011) Formulation and Evaluation Of Metformin Oro-Dispersible Tablets. Acta Poloniae Pharmaceutica Drug Research 68(5): 717-723.

16. Rowe, Raymond C, Walter G Cook, Paul J Sheskey, Marian E Quinn (2012) Hand book of pharmaceutical excipients ( $7^{\text {th }}$ edn) Pharmaceutical place London. 
17. (2007) Indian pharmacopoeia, The Indian pharmacopoeia commission, New Delhi, India.
18. Dash S, Padala MN, Nath L, Chowdhary P (2010) Kinetic Modeling on Drug Release From Controlled Drug Delivery Systems. Acta Poloniae Pharmaceutica-Drug Research 67(3): 217-223.

\begin{tabular}{ll} 
BIOMEDICAL & Assets of Publishing with us \\
RESEARCHES & - Global archiving of articles \\
\hline & - Immediate, unrestricted online access \\
\hline
\end{tabular}

